\title{
Venn Relations of Human Resource: Impact of Human Resource Management on Economy
}

\author{
Gurhan Uysal \\ Ondokuz Mayıs University, Samsun, Turkey
}

\begin{abstract}
Research topic of study is Venn relations. Venn symbolizes relationship among human resource methods. They are personnel management, human resource management, and strategic human resource management. Venn symbolizes relationship among three human resource methods. According to the relations, firms apply three of them in human resource management departments. Personnel management is associated with job performance, human resource management is associated with employee performance, and strategic human resource management is associated with firm performance. Thus, those three purposes are crucial to firm's objectives. This study also explores human resource accounting, cognitive placement, and talent management. Research question is that firms may apply three human resource methods in human resource management departments. Methodology of study is literature scanning and major result is the application of cognitive placement methodology and Venn diagrams. Data and analysis are obtained through secondary data collection.
\end{abstract}

Keywords: human resource management, economy, Venn diagrams, talent management, cognitive placement

\section{Introduction}

This paper is search of Venn relations for human resource management. Further, it has accounting and economy perspectives. Human resource may be related with accounting and it may be related with economy management with concern of gross domestic products.

Human resource is described as core competence of firm. It is intellectual capital and intangible asset. Therefore, it differentiates firm from competitors and it is hard to imitate, for example, a firm can not imitate Donna Karan or Bill Gates. Therefore, talent management is crucial for human resource management and firm management.

Personnel management departments were established in firm structure in 1930s with scientific management revolution. Focus of scientific revolution is jobs and job analytics. Human resource management is related with employee performance and started through 1970s. There is a standpoint difference between personnel management and human resource management. In human resource management, employees are intellectual capital of firm. Therefore, its performance is crucial to firm management. Personnel management's focus is to increase job performance to obtain firm performance.

Strategic human resource management describes relations between employee and firm performance.

Gurhan Uysal, Ph.D., associate professor, School of Business, Ondokuz Mayıs University, Samsun, Turkey.

Correspondence concerning this article should be addressed to Gurhan Uysal at Ondokuz Mayis University, School of Business, 3rd floor, Kurupelit Campus, 55139 Atakum-Samsun, Turkey. 
According to strategic human resource management model, employee performance has an effect on performance of firm departments and department's performance increases firm performance. Therefore, talent management is important to a firm. Because talents have an impact on department's performance, also. Another dimension in American human resource management is human capital. Huselid, Jackson, and Schuler (1997) advocated that human resource management practices ensure firm's human capital to contribute firm's objectives. Relations between human resource management and objectives are crucial for American human resource management. Addition to performance and human capital variables and human resource system thinking has priority in American human resource management. MacDuffie (1995) emphasized impact of human resource system on organizational performance. Human resource system, rather than individual, has an effect on individual performance; and it has an impact on firm performance.

\section{Literature Review: Venn Diagrams}

Traditionally, three are three human resource methods: personnel management, human resource management, and strategic human resource management. Venn relations explain that firm applies three human resource methods together in human resource management department. Because each method has specific mission, therefore, firms apply three human resource management methods simultaneously in organization structure. Personnel management is related with rights of personnel and it operates daily activity of human resource management department. Human resource management aims to increase individual performance of employees and strategic human resource management has firm performance target.

Venn diagrams are concept of mathematics for manager course. It describes relationship of clusters in management. In traditional chronology, there are three human resource methods in firm management. They are personnel management, human resource management, and strategic human resource management. Venn symbolizes that firms apply three of them in their organizational structure. None is ignored. Because each of them has specific mission and purposes. Those mission and purpose exist in business life, currently.

Personnel management continues for daily activity in organizations and it takes enormous effort of human resource professionals. So, there must be personnel management division inside human resource department. Human resource management continues earlier activities of personnel management, such as careers, talents, performance appraisal, and so on. In the past decades, scholars argue notion of strategic human resource. But it is not applied in firm management yet. So, Venn diagrams describe these relations among human resource methods so that three of them must be applied by firms.

In Figure 1, Venn relations show relationship among personnel management, human resource management, and strategic human resource management. Accordingly, personnel management is the smallest curve, human resource management in the middle, and strategic human resource management has the largest curve in the figure. It says that each human resource method is hidden inside each other. Personnel management continues inside human resource management with daily operations; and human resource management and strategic human resource management have employee/firm performance relationship.

Therefore, the figure explains that human resource management departments of firms implement those three human resource methods simultaneously in their organizations. Because mission of personnel management is daily human resource figures, it includes rights of employees; mission of human resource management is to increase employee performance; and mission of strategic human resource management is to impact on firm performance. So, firms are to apply three of them together. 


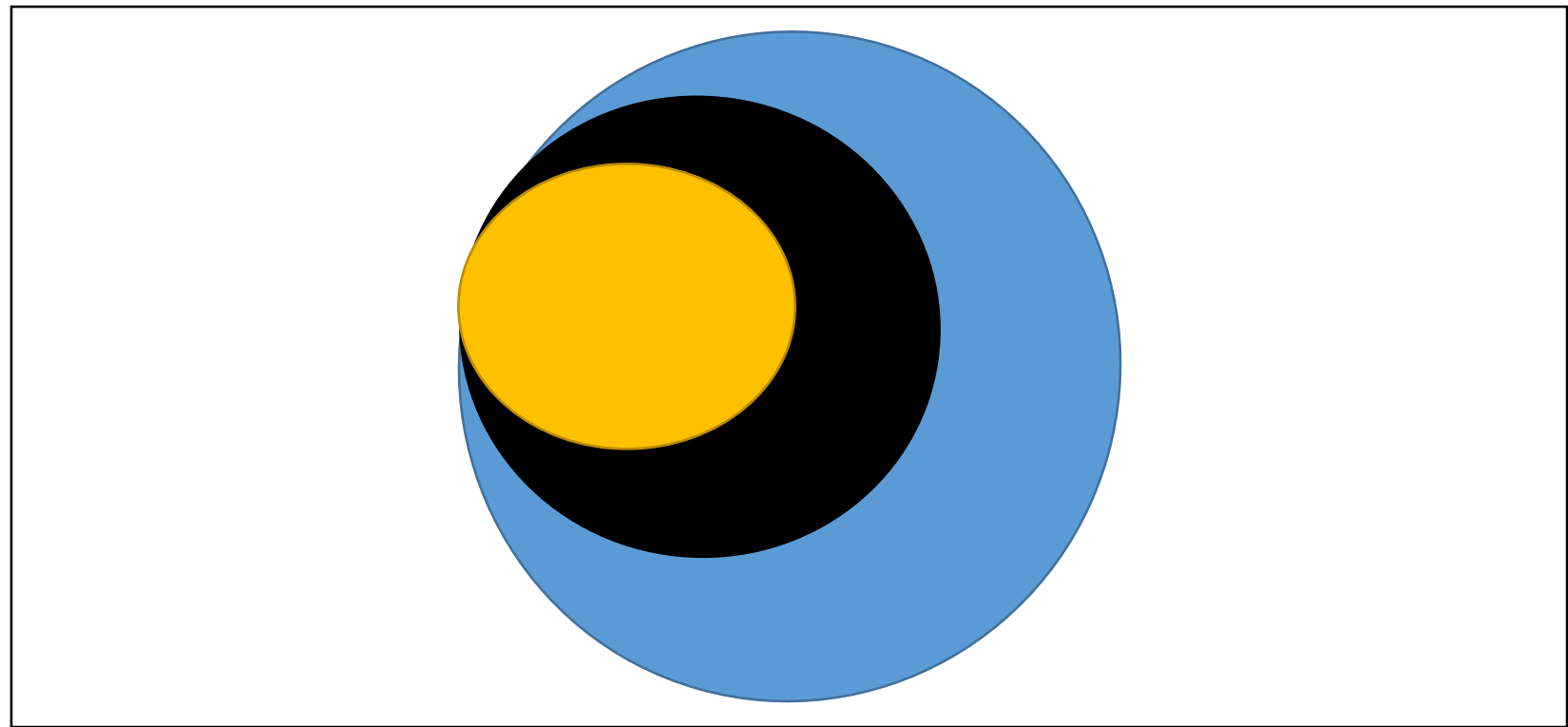

Figure 1. Venn diagrams of human resource.

\section{Talent Management, Human Resource, and Economy}

Talent management is described as appointment of executives into management positions. That definition may have impact on economic results. Firms have organizational departments, such as finance department, logistics department, manufacturing department, marketing, etc. They need managers to effectively manage the department, because these departments generate organizational performance. It (talent management) is important, because performance of managers has an impact on performance of business departments and all departments' performance come together and make up the firm performance, such as market share, sales, profit, and amount of production. Talent management is identified with appointing ability managers to management positions in firms.

Gross domestic product is quantity of production of firm or total sales of firms. Thus, managers make up firms' production and sales. Therefore, talent management is important in firm management and economy. Because talent management appoints talented professionals into management positions, managers and professionals together build firm performance and gross domestic products as total amount of sales and production.

It is expected that managers and professionals increase total sales, profit, and amount and quality of production. Thus, managers may have an impact on national gross domestic product through market sales and production.

\section{Human Resource Accounting: Costs and Benefits}

Kaya (2013) used intellectual capital for human resource accounting field. That study adds human resource-related costs for human resource accounting field. Because managers may observe human resource-related costs via management accounting, new dimension may make human resource accounting as management accounting technic.

Human resource accounting records of costs and benefits of human resource and intellectual capital as intangible assets. Human resource management departments apply various human resource management 
practices. Those practices have a cost itself, such as cost of compensation, cost of staffing, cost of training, cost of industrial relations, and others. Furthermore, human resource is recorded as intangible asset in balance sheet. Thirdly, return on investment of human resource may be matter of financial statement analysis. Human resource management department may compare costs of human resource management practices with benefits of them. Major benefit of human resource might be increasing individual performance.

Human resource accounting may become a technic for management accounting. Because human resource accounting is interested with cost analysis, benefits, budget analysis, and financial recording. Human resource director may track cost and budget limit of human resource through financial recording.

A fictive case study, it is financial human resource transactions of company:

(1) Human resource management department determines personnel budget as 25,000 USD for the term 2016. Board of directors approves this budget limit;

(2) Firm sets a training program in Terma Hotel, Tenessee. Cost of training is 6,000 USD;

(3) Human resource management hires 10 marketing salespersons and two engineers. Cost of staffing process is 2,000 USD;

(4) Total compensation of employees for this company is 20,000 USD. So, cost of compensation is 20,000 USD.

Financial records of those transactions are shown below in Table 1.

Table 1

Records of Financial Transactions

\begin{tabular}{lll}
\hline No. & Records & Money \\
\hline & Management cost & 25,000 \\
1. & Budget & 25,000 \\
& Cash & 25,000 \\
\hline & Management cost & 6,000 \\
2. & Training & 6,000 \\
& Cash & 6,000 \\
\hline & Management cost & 2,000 \\
3. & Staffing & 2,000 \\
& Cash & 2,000 \\
\hline & Management cost & 20,000 \\
4. & Compensation & 20,000 \\
& Cash & 20,000 \\
\hline
\end{tabular}

In the second phase, those records are translated into secondary accounts. This line enables human resource managers to track costs of human resource practices. Thus, human resource manager may implement cost analysis together with budget analyses. Therefore, human resource accounting might become variable of management accounting.

Second analysis of human resource accounting is balance sheet with intellectual capital account. Human resource may be recorded for balance sheet through intellectual capital. Scale of intellectual capital might become yearly-total compensation of firm, for example, intern capital firm hires 1,000 employees and it has 120,000 USD total compensation. So, balance sheet record might become as follows (Table 2). 
Table 2

Balanced Sheet of Intern Capital

\begin{tabular}{ll}
\hline Assets & Liabilities \\
\hline Intangible asset & \\
Intellectual capital 120,000 USD & \\
\hline
\end{tabular}

In balance sheet, human resource is recorded as intangible asset. Variable is total compansation of employees. So, human resource might become management accounting technic.

\section{Cognitive Placement and Talent Management: Determining Individual Performance}

Cognitive placement is one method that is applied by human resource management departments in American firms. This method may be used for talent management to determine best performers. Who is human resource in a company? Answer may become professionals, white or pink. Because they are of candidate for management positions in organizational hierarchy. Therefore, human resource of a firm is professional, manager, and succession planning. They manage the firm and they have an impact on firm performance through individual performance. Therefore, succession planning, recruitment, and performance appraisal may be key for talent management. Those human resource practices hire talents for organizations and evaluate their performance for firm performance.

Talent management is described with appointment of professionals into management positions in organizations. Human resource is defined as core competence of firm. Core competence is resources of organizations and human resource is the most key resource of organizations. It is unique and hard to imitate, because they are intellectual capital, which is unique and not simulated. So, talents or human resources (professionals) may differentiate firm from rivals.

Firms create national gross domestic product in an economy. Its production and sales make up national GDP. Therefore, appointment of white collars (or pink) into managerial positions may be important to competitiveness of a country. Because managers and business departments determine performance of firm, such as market share, sales, profit, and amount of production in the back.

\section{Cognitive Placement and Performance Appraisal: Determines Performers}

Method of cognitive placement determines performance groups among employees. Human resource managers appoint performance grade of employees into one group. Top performers and bad performers are interested in human resource manager. Because top performers make up "talent management" group and bad performers make up "performance management" group. Talents' group might be candidate for management positions, because they have best individual performance; and bad performers may need performance management process to upgrade their knowledge and individual performance. So, scale of cognitive placement is shown in Table 3.

Table 3

Cognitive Placement Line

\begin{tabular}{lllllll}
\hline 1 & 2 & 3 & 4 & 5 & 6 & 7 \\
\hline 100 & 90 & 70 & 50 & 30 & 10 & 0 (grades) \\
& $30 \%$ & $20 \%$ & $20 \%$ & $20 \%$ & $10 \%$ & \\
\hline
\end{tabular}

No. 1 is talent group, who shows best performance in company: Their grades are between 91 and 100. No. 6-7 are bad performing group: Their grades are between 1-19. Human resource managers are to develop their 
individual performance. Because, according to human resource management theory, employee is intellectual capital, who contributes to firm's objectives through individual performance. Thus, none is lost.

Top individual performance has 90-100 performance grade and bads have the lowest 10. Those two groups might be target group for human resource managers and human resource department. Human resource manager replaces top $10 \%$ of employees into top performers and replaces the lowest $10 \%$ of employees into bad performer group.

\section{Methodology}

Case study is used for the study findings. Case study might become appropriate research methodology in human resource management researches. Fictive case study would be used in study.

Think about Extras Company, it has 100 employees for four divisions as finance, accounting, production, and marketing. Human resources obtained performance results from those departments. Human resource manager replaces each performance grade into subgroups in cognitive placement line. Top and bad groups are important for human resource manager. Because top represents talent group in succession planning and bads are performance upgrade group.

In the second phase, human resource manager overviews top and bad groups. Suppose that Mary, Michael, Tumato, and Nicky make up top $10 \%$ in performance grade, Henry, Claudia, and Thomas make the lowest $10 \%$, according to department's manager's performance evaluation.

At the third phase, human resource manager may develop succession planning, promotion planning, or career planning for best employees for managerial positions. Because they are talent and they are candidate for becoming manager in the near future. Bad performers, human resource management departments may develop performance development plan for bad performing group in order to increase their individual performance. Human resource manager determines rotation plan or enrolling MBA programs in universities.

Finding of cognitive placement methodology is that individual performance is important in talent management and cognitive placement methodology may determine individual performance of employees. Individual performance specifies promotion planning for companies. Thus, firms may implement cognitive placement methodology in order to determine individual performance of their professionals.

\section{Research Methodology}

Secondary data are obtained from literature review in study. For human resource accounting and Venn relations, case study is used for analytics in study. It is believed that case study is appropriate method for human resource management study (Uysal, 2015).

\section{Research Results}

Major results of study are that:

(1) Firms apply three human resource methods in their human resource management departments. Venn figures these relations;

(2) Human resource accounting might become management accounting technic for top management;

(3) Human resource management department may use cognitive placement to determine individual performance. 


\section{Conclusions}

To conclude, aim of human resource is to develop positive organizational attitude and behaviours in employee. As in Katou and Budhwar's study (2010), impact of human resource management on employees may be seen on employee skills, attitudes, and behaviours.

Cognitive placement methodology might be used in talent management to determine individual performers for organizational positions. Because managers direct organizations, departments, and organizational goals.

This study might have 6 s contribution for academy literature:

(1) Who is human resources of company;

(2) Human resource is core competence of organizations;

(3) Cognitive placement methodology might be used by human resource management departments to determine individual performance;

(4) Human resource accounting may be technic of management accounting;

(5) Venn describes inside relations between human resource methods;

(6) Human resource of company may have an impact on economic results of nations. Because in economy literature, firms create national gross domestic product. Their sales and production consist of gross domestic products. So, managers direct company for market share, sales, and production. Therefore, human resource or human resource management might have impact on economy through gross domestic products and firm performance.

Finally, there is convergence-divergence debate between European and American human resource management. Convergence appears on firm performance. European human resource management has firm performance orientation, anymore. Brewster (2007) argued stakeholders in human resource management. That may create divergence between Europe and USA for human resource management. Thus, divergence may appear on social partners and societal context.

\section{References}

Brewster, C. (2007). A European perspective on human resource management. European Journal of International Management, 1(3), 239-259.

Huselid, M. A., Jackson, S. E., \& Schuler, R. S. (1997). Technical and strategic human resource effectiveness as determinants of firm performance. Academy of Management Journal, 40(1), 171-188.

Katou, A., \& Budhwar, P. S. (2010). Causal relationship between human resource mangement policies and organisational performance: Evidence from the Greek manufacturing sector. European Management Journal, 28(1), 25-39.

Kaya, U. (2013). Human resource accounting. Istanbul: Beta.

MacDuffie, J. P. (1995). Human resource bundles and manufacturing performance: Organizational logic and flexible production systems in the world auto industry. Industrial and Labor Relations Review, 48(2), 197-221.

Uysal, G. (2015). From World War 1st to World War 2nd: IS-LM curve and 1929 crash. Journal of Business and Economics, 6(11), 249-252. 